\title{
Om de danske Dialekter i Sønderjylland
}

\section{Af Anders Bjerrum.}

De sønderjyske Dialekter hører til den jy ske Gren af de danske Folkemål. De vigtigste Kendetegn på Jysk er to Novationer, som enten slet ikke eller først i nyeste Tid har fundet Sted i de øvrige danske Dialekter. For det første har Jysk bortkastet det ubetonede -e i Slutningen af gamle Tostavelsesord; i Ømålene hedder det komme som i Rigssproget, men i Jysk hedder det komm uden -e. Denne Ejendommelighed er over 650 År gammel; Flensborg Stadsret, som er skrevet i Slutningen af det 13. Århundrede, har som Regel bevaret de gammeldanske lange Former, fx bøtce (bøde), krauce (kræve), kunce (Kone), men en Gang imellem slår Skriverens jyske Dialekt igennem, og han skriver fx ygh (Øje), woon (Vane), sin sworn brothcer (sin svorne Broder). - For det andet har største Delen af Jylland allerede i Middelalderen opgivet den gamle Forskel mellem Hankøn og Hunkøn, som endnu for kort Tid siden var bevaret overalt på Øerne. Kun i Yderkanter, i Vendsyssel og i det østligste Djursland, skelnes der $\mathrm{i}$ de gamle Sprog endnu mellem Hankønsord og Hunkønsord.

Inden for Jysk hører Sonderjysk til de sy dve stjyske Dialekter, især ved at have foransat bestemt Artikel (œ Ko, ce Hus, ce Børn) modsat de øvrige Dialekters Vexlen mellem efterhængt og foransat Artikel (u d e n Attribut: Koen, Huset, 
Børnene; m e d Attribut: den brogede Ko, det nye Hus, de Pokkers Børn). Grænsen mellem Sydvestjysk og Nordvestjysk går omtrent fra Bulbjerg i Vester-Han Herred gennem Hjarbæk Fjord over Skanderborg til Horsens.

Inden for de sydvestjyske Dialekter igen er de sønderjyske Dialekter altså sønderjyske. Men hertil er at sige, at der ikke kan påvises nogen bestemt Nordgrænse for Sønderjysk. Der findes et $\mathrm{Gr}$ r n s b b l t e, der strækker sig fra Kongeåen og ned til en Linie fra Skærbæk til Genner; ja vi kan gå endnu længere mod Syd, fx til enı Linie fra Tønder til Åbenrå. Og en Del af de sønderjyske Ejendommeligheder genfinder vi i helt andre Egne af Jylland, fx i Thy eller ved Århus. Hvordan skal det forklares?

Vi søger at finde et Svar ved at betragte nogle sønderjyske Sprogprøver og gøre Rede for nogle af de vigtigste Forskelle mellem dem. Vi begynder længst mod Nord.

I Rødding er en af de sønderjyske Dialektdigtere født, nemlig Chr. Seeberg, som har udgivet Digtsamling En jenle Kaels Jul (1928). Et Par Strofer af denne Samling er nok til at give et Indtryk af Røddingegnens Dialekt.

Hven a kommer hjem te mi ejen Gård så er a så glaj som en Skreje, de er akkurat som mi Hjart den slår lidt raske end hejsen den pleje.

AE Tag er lidt vinsk å ce Vinre skjøew - de er ingen Palads te a eje men glante som her kund a alle løow, om osse a haj et lidt beje.

(Når jeg kommer hjem til min Gård, så er jeg så glad som en Skrædder, det er akkurat som mit Hjerte slår lidt hurtigere end det ellers plejer. Taget er lidt vindt og Vinduerne skæve - det er intet Palads jeg ejer $\longrightarrow$ men mere tiltalende end her kunde jeg aldrig leve, om også jeg havde det lidt bedre). 
Mange Sønderjyder synes vist, at dette ser helt nørrejysk ud. En af de nørrejyske Ejendommeligheder er nu kun tilsyneladende; i Røddingegnens Dialekt er h stumt i hjem og Hjart som i de øvrige sønderjyske Dialekter. Ved at se nærmere efter, cpdager vi også en Del specielt sønderjyske Træk; bl. a. er Vokalerne helt forskellige fra de nørrejyske; det hedder fx ikke glå som Nord for Kongeåen, mien glaj, og det hedder ikke Gord, men Gård.

Alligevel or der en Del Ejendommeligheder, der er nørrejyske. Den mest påfaldende er måske den, at „jeg“ hedder $a$ og ikke $\mathfrak{x}$. Grænsen mellem $a$ og $\propto e$ går fra lidt Syd for Ribe til lidt Syd for Haderslev. Desuden hedder „jeg“ $\alpha$ i et helt andet Hjørne af Jylland, nemlig i Thy. Hvad er nu ældst, $a$ eller $\propto$ ? I nogle af de ældste Håndskrifter af jyske Lov hedder „jeg“ $a k k$, i andre ak. Af disse to Former må de nuværende jyske Former $\propto$ og $a$ være opstået ved at $\mathrm{k}$ er forsvundet ligesom $\mathrm{i}$ Ordet og, der i Gammeldansk hedder ok, men nu udtales å. Af de to Former cek og ak må cek være den ældste, fordi det er den, vi finder allerede i Folkevandringstidens urnordiske Runeindskrifter, fx på det lille Gallehushorn. Altså er den Form, Ordet har i Sønderjylland og Thy, ældre end den, det har i det øvrige Jylland. Og nu synes vi, vi begynder at forstå den mærkelige Overensstemmelse mellem Sønderjysk og Thybomålet: Etsteds i Nørrejylland er ak åbenbart blevet til $a k$, og den nye Form har så bredt sig til Siderne som en Bølgering, når man kaster en Sten i Vandet. Men Bevægelsen er standset, inden den nåede helt ud til alle Yderkanter, således at Halvøens sydligste Del og dens nordvestligste Hjørne beholdt den ældre Form.

En anden Ejendommelighed ved Rødding-Dialekten er den, at det hedder mi Hjart de $n$ slår. Ordet Hjerte er altså Fælleskøn. Nordvestslesvig danner nemlig den sydligste Spids af et stort vestjysk Område, hvor Fælleskøn og Intetkøn er fordelt på en helt anden Måde end i de øvrige jyske Tokønsdialekter. 
Alle Ord for Ting, der kan tælles, er Fælleskøn i Vestjysk; det hedder altså den Hus, en Barn og den Trœ, når der tænkes på et voxende Træ. Alle Ord for Ting, der ikke kan tælles, er derimod Intetkøn; Vestjyden siger altså: det Sne, meget Modgang, noget Tyskhed og det Træe, når han tænker på Træ som Materiale. Denne vestjyske Brug af de to Køn er en Nydannelse. Altså har den nordlige Del af Sønderjylland også her fået det nye, medens den sydlige Del har bevaret det gamle.

Som en tredie og sidste nørrejyske Ejendommelighed skal nævnes, at Røddingmålet mangler Omlyd $i$ prcesens af Verber. I de citerede Strofer er der to Exempler: a kom m e r hjem og mi Hjart den $s$ l år. Lidt længere mod Syd hedder det slcer og lidt længere endnu kømmer.

Det er et gammelt Træk ved de nordiske Sprog, at nogle Verber har i-Omlyd i præsens singularis. Den findes i Vestnordisk og også i Jydske Lov og Flensborg Stadsret. I det Afsnit af Flensborg Stadsret, hvor der fastsættes Bøder for Sår og Overlast, står der fx.: For bien stungan saar scex mark, For hvcert bien thcer $v t$ af saar $g \propto \propto r$ bøtces thre mark for. (For benstunget Sår, dvs. Sår, der når ind til Benet, sex Mark; for hvert Ben, der går, dvs. kommer, ud af Såret, bødes der tre Mark); i næste Paragraf hedder det: Hwo sum $s l \propto \propto r$ anncen (Hvo som slår en anden). Derimod er der $\mathrm{i}$ den øvrige Del af Danmark allerede i Middelalderen sket den Forenkling i Bøjningen, at præsens har fået samme Vokal som infinitiv. De nye Former, går, slår osv., har åbenbart bredt sig ud over den jydske Halvø på lignende Måde som $a k$, $a$. Kun på to Steder, begge i Halvøens Udkanter, har nogle af de gamle Former holdt sig, nemlig ved Jyllands Østkyst $i$ et Område, der når fra Vejle til Grenå, og i Sønderjylland. Jo længere vi kommer mod Syd i Sønderjylland, des flere omlydte Præsensformer finder vi. I Fjolde $i$ Sydslesvig hedder det $\mathrm{fx}$ a fecer, a gecer, a slecer, w stecer, a kømmer, w hcer (har), œ falder (falder), ce tœbber (taber), der smagger (det smager), w hcelder (holder; i-Omlyd af o gi- 
ver ø; men holde hedder i Gammeldansk haldce med a, og i-Omlyd af a giver $æ$, så det er i den fineste Orden), ialt findes der i Sydslesvigsk godt en Snes omlydte Præsensformer. Nord for en Linie fra Tønder til Åbenrå har vi kun Omlyd i $\propto$ fæer, œ gœer, œ nœr (når), w sloer og œ stcr. Her siger man altså ikke $\propto$ hær og $\propto$ kømmer, men $\propto$ har og $\propto$ kommer. Fx i følgende lille Prøve på Rømøsk (optegnet 1930 af Forf. efter Fru Emilie Tønnes, København):

AE Sønderlands Pigger di vår meer rask $i$ de, å Margrete a o Smoejs hu såj ålti: AE Sonderlands Pigger di kommer lisom „Vi har vos jon, vi har vos joen!", men $œ$ Nörlands Pigger di kommer som „U foer vi joen, $u$ for vi joen?“.

(De S $\varnothing$ nderlands Piger - Pigerne fra den sydlige Del af $\emptyset$ en de var mere raske $i$ det, og Margrete af Smedens hun sagde altid: De S $\varnothing$ nderlands Piger de kommer ligesom * Vi har os een, vi har os een!«, men de Nørlands Piger de kommer som s Hvor får vi een, hvor får vi een? $\mathrm{k}$ ).

På Grund af Øens isolerede Beliggenhed indtager dens Dialekt en særegen Stilling blandt de sønderjyske Folkemål. Dels er der her sket nogle Nyudviklinger, som ikke er sket andetsteds, dels har Dialekten bevaret en Del gamle Træk, som er forsvundet på Fastlandet lige over for. Blandt Nyudviklingerne kan der være Grund til at pege på to. Den ene har kun ringe Betydning, men overrasker alle fremmede: Pronominerne han og hun har mistet deres n cg hedder ha og $h u$. Den anden har derimod Betydning for Dialektens hele Lydsystem: Efter visse gammeldanske lange Vokaler, $\bar{i}$ og $\bar{y}$, er der opstået en ejendommelig Lyd, der nærmest ligner kj- i Rigssprogets Kjole, og efter $\overline{\mathfrak{u}}$ en Lyd, der ligner et $\mathrm{k}$. En Bi hedder altså Bikj, ni hedder $n i k j$, en Kvie Kvikj, og en Side $S i k j$; ny hedder $n y k j$ og byde bykj; en Mur hedder Mukr, en Uge Uk og en Frue Fruk. Den nye k-Lyd findes altså ikke blot i gammeldanske Enstavelsesord, men også i gammeldanske To- og Flerstavelsesord. På Fastlandet har vi en lignende Lyd, der efter u lyder som $\mathrm{k}$, men efter i og y nærmest som tj, fx i Mukr (Mur), nytj (ny) 
og nitj (ni). Men her findes den kun i gammeldanske Enstavelsesord, altså i Ord, der i Rigssproget har Stød. Og i de vestslesvigske Dialekter, hvor den findes, har den nøjagtig samme Funktion, som Stødet har i andre Ord, fx forsvinder den ligesom Stødet, når Ordet står tryksvagt i Sætningen. Man har derfor tidligere ment, at den mærkelige Lyd ligefrem er opstået af Stødet. Men for nylig har cand. mag. Gunhild Nielsen påvist, at den findes på Rømø, der ikke har Stød, og her også forekommer i Ord, der aldrig $\mathrm{k}$ a $\mathrm{n}$ have haft Stød, og dermed falder den gamle Forklaring. Den nye Lyd er forøvigt nu kun bevaret i de gamles Sprog i Vestslesvig, men har tidligere haft en meget videre Udbredelse; sả langt mod Øst som i Bovlund og Hønkys, ja helt ovre på Årø er der fundet Spor af den. Men Rømøboerne er konservative og bliver ved med at sige en nykj $M u k r$. Og de har åbenbart også vist sig konservative deri, at de har bevaret den nye Lyd også i gamle Tostavelsesord, mens Fastlandsboerne - også Nørrejyderne - har gjort den til en Slags Fkvivalent til Stødet, der kun, eller næsten kun, findes i gamle Enstavelsesord.

Blandt de gamle Træk, der er bevaret på Rømø, er den vigtigste iøvrigt, at Dialekten ikke har Stød og har bevaret den ældgamle Forskel mellem to tonale Ordaccenter (singularis Gren udtales uden Stød, med jævn, forholdsvis lav Tonegang, pluralis Gren med en ujævn Tonegang, der først stiger stærkt, derefter falder og til sidst stiger lidt igen). Stødet er en Novation, der formodentlig er trængt ind nordfra. Den når til en Linie, der går Nord om Rømø, Syd om Tønder, derfra Syd og Øst om Tinglev og så i en Bue mod Nord bg Øst, Nord om Haderslev. Nord for denne Linie er der et Område, der både havde Forskellen mellem Stød og Ikke-Stød og Forskellen mellem de to tonale Accenter. Syd for Linien er der ved Tinglev nogle Landsbyer, der hverken har Stød eller tonal Accent, men ligesom Lollikerne klarer sig uden. 


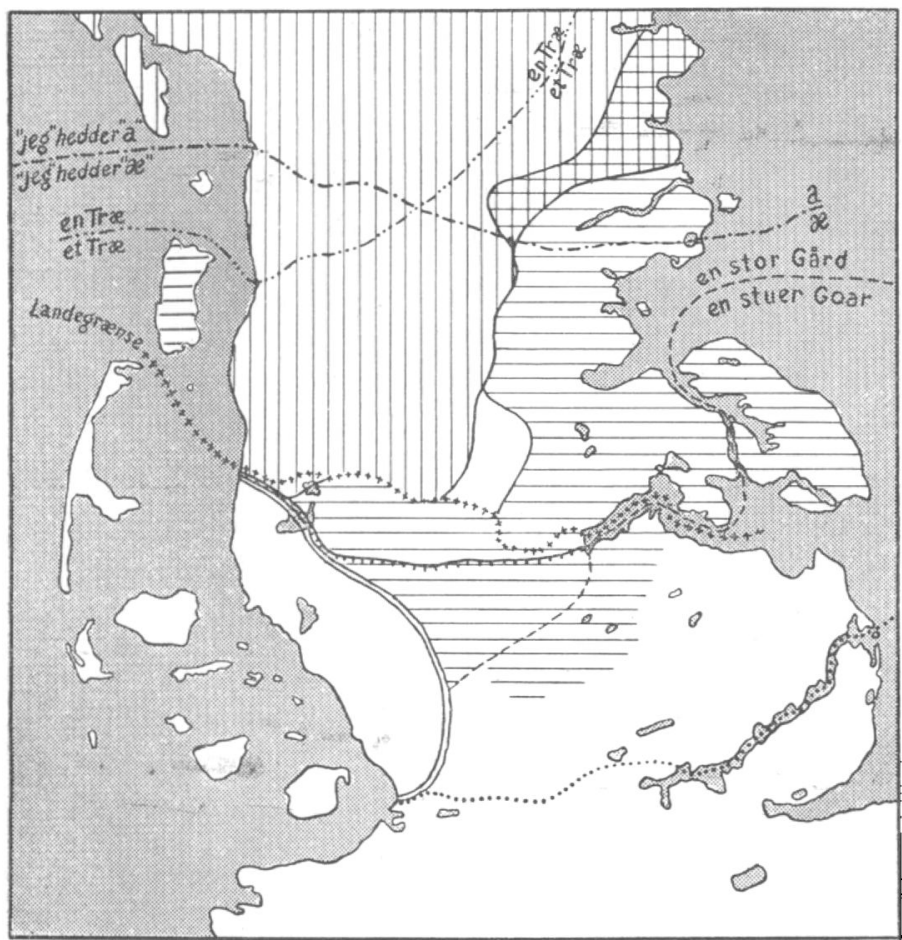

TIStød i HUS, $\quad \cdots$ Omtrentlige Sydgranse f.alm.dansk Omgangssprog nu. GR̊RO, KO 0.5.

Tonale Accenter $=$ Ostgranse for Frisisk ca 1885.

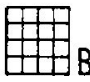

Både Stod og tonale Accenter

Hverken $-"-e l l e r-"-\cdots-$

Stødgrænsen er langtfra den eneste Linie, der deler Sønderjylland $\mathrm{i}$ et nordvestligt og et sydøstligt Dialektområde. Tværtimcd, en stor del af Grænselinierne gennem Sønderjylland går på skrå, de fleste omtrent fra Tønder til Åbenrå eller Haderslev. Nogle af disse Grænser er vigtige. Mod Nordvest har en Del af de svagtbøjede Verber (de der i Rigssproget har 
præteritum på -ede) Præteritumendelsen' -et; her hedder „blinkede“ altså blinket, „piskede“ pisket og „vaskede“ vasket. Mod Sydvest er den tilsvarende Præteritumsendelse -e eller -er (på Sundeved er $r$ stumt i Udlyd undtagen foran Ord, der begynder med Vokal), således at præsens og præteritum er faldet sammen i disse Verber; fx betyder blinke både "blinker" og „blinkede“, og vaske både „vasker“ og „vaskede“. Mod Nordvest udtales det ubetonede "det" som et, mod Sydøst som e eller er. Nordvestslesvig slutter sig i denne Henseende til Nørrejylland, Sydøstslesvig derimod snarere til Øerne, som har $e ð$ og $e$. En iørefaldende Ejendommelighed, som Folk driller hinanden med dernede, er den, at det nordvestlige Område har $v$ og åbent $g$ svarende til gammeldansk $\mathrm{p}$ og $\mathrm{k}$ (Rigssprogets b og g) mellem Vokaler i Ord som taver (taber). Vivver (Viber), Sager, skrigger (skriger), men det sydvestlige Område henholdsvis $f$ og en Lyd, der ligner det tyske ch: tafer, Viffer, Sacher, skricher.

En enkelt Grænselinie går på langs gennem Sønderjylland fra Nord til Syd. Allerede Lyngby skelnede mellem Vestslesvigsk, hvor det hedder œ vår (jeg var), œ sår (jeg sad) og œ $d r a ̊ k$ (jeg drak), og Østslesvigsk, hvor det hedder œ var, œ sar, ce drak. Denne Grænse fortsætter mod Nord, således at Vestslesvig også i denne Henseende hører med til Vestjylland, medens Østslesvig hører sammen med det øvrige Jylland.

De fleste af disse Forskelle mellem Vest og Øst eller Nordvest og Sydøst vil Læseren finde Exempler på i de følgende to Sprogprøver, den første fra Nordvest-, den anden fra Sydøstslesvig.

Hviding Herreds Mål. Anekdote om Studehandel, optegnet 1939 af Forf. efter Peter Højer i Gånsager, Vodder Sogn.

No veer a jo $\epsilon t$, om de vår Andes a a Lykk hcelder de vår Mads Jåkkob fra Vellerup - han køør te Var Mcrkend. Da haj di enner Feervuun, mon di hajj sån lott $K a-$ stenvuun ma Agstool te, ̊̊ dœmm køør di å heel darne€r. $\AA$ da haj vi €nner Scerrel snar, de vår Speesiger, å 
sả haj di œen Pcecengkas $i$ æe Agstol å œ Kat om œ Lyw. Ha $n$ køør jo. $A$ Hans Skolmester han gek, heel te Var, $i$ trảtt jam; han skør jo Gjœnvœj åmcelld, får dar gik jo Stii. A så kcexnd han Asen kom cetter et a Foorvark. $A$ han ströwwet - han gik jo liig te moe an Sti, doend an sku jo cen Slenk urren om - a han roft å ham; mon ham te dœr køør han vest jo et, van de vår, a han pisket ả ce Hcecest, får han veld jo et ha ham op å ag. De vår ves neer ved Bramming. $A$ Hans Skolmester han mått jo gå, $m æ$ a Kat om a Lyw, å diend vår svar, heel te Var.

$D i$ tåw Söwren toejj mce enner frommer op $\stackrel{a}{a}$ ag, de $k a$ do stool å; di sår jo mce œ Pcecengkas i œ Agstol.

( Nu ved jeg jo ikke, om det var Anders af Løkken, eller det var Mads Jakob fra Vellerup - han kørte til Varde Marked. Da havde de ingen Fjedervogne, men de havde sådanne lette Kassevogne med Agestole til, og dem kørte de på helt derned (de'gamle sagde jo n ed til Jylland, men op i det tyske). Og da havde vi ingen Pengesedler næsten, det var Specier, og så havde de en Pengekasse i Agestolen, og Fengekatten om Livet. - H a n kørte jo. Og Hans Skolemester han gik, helt til Varde, og trak hjem (med de indkøbte Stude); han skød jo Genvej nu og da, for der gik jo Stier. Og så kendte han, Asen komme efter det, Køretøjet. Og $\mathrm{h}$ a n skyndte sig - han gik jo lige til ad en Sti. den anden skulde jo et Slag uden om - og han råbte på ham; men ham, der kørte, han vidste jo ikke, hvem det var, og han piskede på Hestene, for han vilde jo ikke have ham op at age. Det var vist nede ved Bramminge Og Hans Skolemester han måtte gå, med Katten om Livet, og den var tung, helt til Varde. - D e tog Søren tage mig ingen fremmede op at age, det kan du stole på; de sad jo med Pengekassen i Agestolen).

S u ndevedmå l. Felsted Sogn. Brudstykke af Nikolaj Andersens Digt om Per Volle, der ikke lod sig imponere af Krigen i 1864 (Sønderjydske Aarbøger 1890).

Aa Als ve e Straend sad Px Voller o' vaske

Sin Förrer en Daw, hvad di sawt haj behow,

$O$ ' oldt som hand sad der, e Kulle di klaske

O' fløjde deröw'e fra Sandbjerreskow. 
En an haj da no vel nok reest sce omsi'e

$O$ 'endl'e se te, en kom om a e Vej;

For etter en Kuul' e' di farrest kun ti'e,

Hvad enten di sin e' Soldåt' heller ej.

Men Pede hand ladt sa itt' rokk' o' itt rø'e,

Hand sad de' så roler o' vasker o' ned,

Som kund' hand e Pif'end o' Susend itt' ho'e,

Som kund hand e Ryg'end o' Smyg'end itt' se.

Nej, itt' te hans Öjn di să möje som blinke,

Hvo tit o' e Kulle di flöj ham fobi;

Men öwer ebag ståj di ander o' vinke

Te Peder o' öjt', han skuld ströw å kom hid:

„Så kom da no Pede, herom bag e Skandse!

E' do da mondt tumbe, hvad tanke do vel?

Kand do da itt' mark' te e Kulle di dandse,

O' vil do da ha, di skal sky doe ihjel?"“

I tæenke vel, Pede no lof som en $\mathrm{Ha}^{\prime} \mathrm{e}^{\text {? }}$

Jo, pyt! Nej hand lånd' dern et Blik som en Dolk

O' lee' så foragtle o' hånt, law hand sva'e:

„Di skyrre fo' Skam da vel itt ette Folk?!“

( $P$ å Als ved Stranden sad Per Volle og vaskede sine Fødder en Dag, hvad de sagtens havde behov, og alt mens hans sad der, klaskede og flojtede Kuglerne derovre fra Sandbjergskov. En anden havde dog nu vel rejst sig omsider og endelig set til, at man kom (om) af Vejen, for efter en Kugle er kun de færreste tidige (trængende), hvad enten de så er Soldater eller ej. Men Peter han lod sig ikke rokke og ikke røre, han sad der så rolig og vaskede og gned, som kunde han ikke høre deres Piben og Susen, som kunde han ikke sr. Røgen og Smøgen. Nej, ikke at hans Øjne de så meget som blinkede, hvor tit også Kuglerne fløj ham forbi; men ovre bagved stod de andre og vinkede til Peter og råbte, han skulde skynde sig at komme hid: sSå kom da nu, Peter, herom bag Skanserne! Er du da mon tosset. hvad tænker du vel ஹå? Kan du da ikke mærke, at Kuglerne 
de danzer, og vil du da have, de skal skyde dig ihjel? « — I tænker vel, Peter nu løb som en Hare? Jo, pyt! Nej han lånte dem et Blik som en Dolk og smilede så foragteligt og hånligt, da han svarede: *De skyder for Skam da vel ikke efter Folk?!«).

En Forskel mellem Nordslesvigsk og Sydøstslesvigsk, som tilfældigvis ikke rigtig kommer frem i disse Prøver, er den at Adjektiverne ender på -t i Intetkøn mod Sydøst, mens de fleste Adjektiver mangler Kønsbøjning mod Nordvest. På Sundeved hedder det altså røt Saend (rødt Sand), men i Hviding Herred roo Saend. Ligesom i Nordslesvig findes der også i det allermeste af Nørrejylland kun ganske få Adjektiver, der kan bøjes i Køn (god-godt, hård-hårdt og enkelte flere). I de danske Ømål lígesom i Rigssproget har næsten alle Adjektiver derimod Kønsbøjning, og det samme er Tilfældet med Als, Åbenråegnen, Sundeved, Angel, Mellem- og Sydslesvig. Her kan endog føjes - $t$ til enkelte Adjektiver, som ikke kan få - $t$ i Rigssproget ( $\mathrm{f}$ et trot $\emptyset \mathrm{g}$ ).

De Sprogprøver, vi hidtil har beskæftiget os med, er fælles om een Ejendommelighed, som giver de fleste sønderjyske Dialekter en Særstilling i Forhold til de nørrejyske Dialekter og tildels også Ømålene: De mangler de karakteristiske Diftonger ie, yø, uo i Ord som hiel (hel), kyør, kyøre (køre), Stuol (Stol); i de foregående Texter har disse Ord de samme Vokaler som i Rigssproget: heel, køør (kørte), Agstool (Agestole) Der findes ganske vist to Ting, der tyder på, at også Nordslesvig en Gang har haft disse Diftonger. For det første er de almindelige i Flensborg Stadsret: bien (Ben), gwoth (god; $w$ betegner her u). For det andet har Dialekterne bevaret enkelte Ordformer, der synes at gå tilbage til ældre Diftonger, fx jerer (hedder; Flensborg Stadsret har hieter), jøster (øster), Volle (Ole). Men nu er som sagt Diftongerne forsvundet $i$ den allerstørste Del af Sønderjylland. De findes kun på Als, i Angel og i Sydslesvig. I den følgende Prøve fra Als er der nogle Exempler. 
A lsing e rdansk. De to første Strofer af et Digt, som den bedste nulevende sønderjyske Folkemålsdigter, Martin $\mathrm{N}$. Hansen, har skrevet om Afstemningsdagen i 1920. Digtet hedider „En stue daw“ og er trykt i Samlingen „Hvæ fowl må syng -“ (1924). Dialekten er fra Notmark Sogn.

\author{
Nej, no hoe a ålde sett, \\ komme, komme, komme! \\ si hvo åldt $x$ rødt å hvedt, \\ sæj, hva tøss i om $\epsilon$ ? \\ Si kon øvr e hiele by \\ œ dse flagg, å di ce ny. \\ di skal rigte prøwwes. \\ Ja, de blcess - mon få di kast \\ vel e flagg di hoelde? \\ A e daw må vi sto fast, \\ få no ret de gjoelde. \\ $J a, \in$ daw da må vi hå \\ de, vi stri å kcempe få \\ $i$ di månne oa.
}

(Nej, nu har jeg aldrig set - kommer, kommer, kommer! (Bydemåde). Se, hvor alt er rơdt og hvidt, sig, hvad synes I om det? Se kun, over hele Byen er der Flag, og de er ny, de skal rigtig proves. Ja, det blæser - mon for de Vindst $₫ d$ vel Flagene de holder? Og i Dag må vi stå fast, for nu gælder det ret. Ja, i Dag da må vi have det, vi stred og kæmpede for i de mange $A$ r).

Det hedder altså fx e hiele by og En stue daw. Men foruden de tre Diftonger ie, yø cg uo har Alsingermålet - og ligeledes Angelbomålet og Fjoldemålet - endnu en fjerde og en $\mathrm{f} \in \mathrm{m}$ te Diftong, nemlig eæ og oa. På den sidste er der et enkelt Exempel i de citerede Strofer, nemlig $i$ di månne oa. Denne Diftong er vistnck en Novation, som er kommet østfra. I dette Tilfælde har vi altså de nye Ordformer mod Øst, på Als, på Angel og i Sydslesvig, medens de gamle Ordformer er bevaret mod Vest. 
M e 1 le ms lesvigs k. Omtrent midt i Sønderjylland ligger Frøslev. Den omtalte Påvirkning fra Øst er ikke nået så langt vestpå, og kun enkelte af de ovenfor omtalte Påvirkninger fra Nord er nået så langt mod Syd. Frøslev er jo den eneste Landsby i Hanved Sogn, som kom med til Danmark. En stor Del af Eren for Danskheden i Frøslev tilskriver man Kromanden Carsten Thomsen, Sønderjyllands forste og bedste Dialektdigter. Det følgende Digt hedder Law Jens kom hjem. Handlingen foregår i Høsten 1848, da den første Våbenstilstand var sluttet. Den lille Konflikt i Digtet foranlediges ved, at en Del slesvig-holstensk sindede Soldater var rømt fra den danske Hær.

De vår en Daw i Høstens Ti,

Da Prers slow Row for fuld',

Der vår inne hjemm undtejn Mari, som kogh e Unnen skuld'.

Hun sysselt olt, $\dot{o}$ visked aw I Dørensk, Boj ò Kammer;

Hun strø hvidt Sahn så kønt e Daw

ò fejed e Pissel i Flammer.

I e Køghen skén bo Kand' ò Kehl,

ò rén vår Pand' ò Grye,

$A$ e Aren brcehn en lyste Ehld,

Hun kund e Køghen stye.

Hun haj e Sopgry øwwerhahn

O tørt e Sved a e Kinne;

Hun pust lidt aw ò gik et Vochn

Hen ò se ud a e Vinne.

Men hva vår de? hun bløw så hop

o rod i e Hoj som en Rohs;

Hun pynte sa, ò strøg så op

Hin Hår, ó médt en Hohs. 
Ja Hillemind! der kom en Mand Med Tvœrscek, Stok ò Pihf, O lig op a e Bro kom han, No vår de let ò begrihf.

For de vår Jens, der kom frå Kri, Han så e lidt bedrøwwe; Men da han fik Sigt å Mari, Kan nok voe, de vår øwwer.

Han kom derind; "Goddaw Mari!" - Soj han vel nok så glcejle "Hvo hce do bløwwen køhn den Ti, Law ce vår henn, ja dejle!"

Så vild ha tej fat å hin Hahn, Men de vild hun it lie; Hun vår nok it så godt istahn, Da hun vild te å sie:

„Min kjœrre Jens, do hœe dò it Rend frå din Kammeråter! For der vår nok, der dowt kuns lidt Iblan vor Kongs Soldåter.

Der ha kommen nowwe skrailend Den slesvig-holstens Vihs, o for vos Danske, sto ò små. Vår de int vie Lihs!“"

- „Nej, kjarre, søde lill Mari, Hvor kan do tro så tombe, Te $\propto$ skuld øw Forrcederi ò føhr moe op så lompe?

Nej jen ò tywens Regement Ha gor sin Pligt te Prikk', 
E Kong han hœ vos oll hjemsendt,

Min Pass er i min Fikk'.

O faer vi ret no Kri igjen,

Så kan do tro, min Pigh,

Te ce skuld hjoelp som dygte Svend

o jaw e Fihnd a e Rihg!"

Mari bløw glaj te de gik vidt, o rådt hin Hahn så jøwwer;

- Men hvad så mér? - de véd a it -

E Sopgry den kogt øwwer.

(Det var en Dag i Høstens Tid, da Pers mejede Rug for fuld Kraft, der var ingen hjemme undtagen Marie, som skulde lave Middagsmad. Hun gjorde allerede i Stand og tórrede af i Dagligstue, Bod (dvs. Spisekammer) og Pigekammer; hun strøede hvidt Sand så pænt i Dag og fejede Sandet på Storstuegulvet i Flammemønster. I Køkkenet skinnede både Kande og Kedel, og ren var Pande og Gryde, på Arnen brændte en lystig Ild, hun kunde regere Køkkenet. Hun havde fået hængt Suppegryden over og tørrede Sveden af Kinderne; hun pustede lidt af og gik et Vend hen at se ud af Vinduet. Men hvad var det? Hun blev så betuttet og rơd i Hovedet som en Rose. Hun pyntede sig og strøg så op sit Hår og målte en Strømpe. Ja Hillemænd! Der kom en Mand med Tværsæk, Stok og Pibe, og lige op ad Gårdspladsen kom han, nu var det let at begribe. For det var Jens der kom fra Krig, han så lidt trist ud; men da han så Marie, kan det nok være, det var ovre. Han kom derind; -Goddag Marie! « sagde han nok så glad - ^hvor er du blevet pæn i den Tid, jeg var borte, ja dejligt! \& Så vilde han tage fat $i$ hendes Hånd, men det vilde hun ikke have; hun var nok ikke så vel til Mode, da hun vilde til at sige: "Min kære Jens, du er da vel ikke lobet fra dine Kammerater! For der var nok, der kun duede lidt, iblandt vor Konges Soldater. Der er kommet nogle skrålende på den slesvig-holstenske Vise, og for os danske, store og små, var det ikke nogen videre Lise! $\ldots \rightarrow$ Nej, kære, søde lille Marie, hvor kan du tro så tosset, at jeg skulde øve Forræderi og opføre mig så lumpent? Nej een og tyvende Regiment har gjort sin Pligt til Punkt og Prikke, Kongen har hjemsendt os alle, mit Pas er i min Lomme. Og får vi ret nu Krig igen, så kan du tro, min Pige, at jeg skal/hjælpe som dygtig Karl med at jage Fjenden ud af Riget! * - Marie blev glad så det gik vidt, og rakte sin Hånd så ivrigt; $\longrightarrow$ Men hvad så mere? - det ved jeg ikke - Suppegryden den kogte over). 
Dialekten er vestslesvigsk, for så vidt som det hedder $D e$ $v$ å $r$ en Daw med å og ikke a. Men ellers hører den i de fleste Henseender til de sydøstslesvigske Dialekter: Den har tonale Accenter og mangler Stød; den har Sammenfald af præteritum og præsens i Former som pynte (i visked og fejed er d overtaget fra Rigssprogets Ortografi ligesom i rød, som udtales rø); Adjektiverne bøjes i Køn: køhn : kønt, hvidt Sahn; den gamle Præsensform af Verbet have er bevaret: $E$ Kong han $h \propto$; men der findes ingen Diftonger: rén, rød Rohs, Hår, Pars.

A n g e l b o m å l e $t$ har som sagt Diftonger $\mathrm{i}$ disse fem Ord. Det ligner i mange Henseender Dialekten på Als, men afviger fra den på to Måder. Dels har det bevaret flere gamle Træk, dels har det optaget mange flere tyske Låneord; Påvirkningen fra Nord og Øst er altså svagere end på Als, Påvirkningen fra Syd stærkere. Den følgende Historie om Konen fra Langbjerg og Kong Frederik VII er fortalt af Helene Thomsen på Lille Solt Mark. Meddeleren, hvis egentlige Modersmål var Nedertysk, var ikke helt sikker i den danske Dialekt og har et Par Steder anvendt tysk Ordstilling; men iøvrigt er Sproget i det væsentlige korrekt.

Dear va cen gammel Kuun frå Långbjerre, hind Mand va dø. Hun ho jen Sön, hand jet Pecr; hand va Soldåt, hand tiend ve a Leibgarde $i$ Københawn. Hun vild nåk atte Lyksborre $\ddot{a}$ tal ce Kong. Så gik hun a Stæj mae Trask ma blank Boand cm, ̊̊ œ Skirm ynder œ Arm. Law hun ankom i Lyksborre, spuu hun $\propto$ Posten, om hun it mot tal $\propto$ Kong. Så kom $\propto$ Tenner å so, hun måst kom ind. Law hun da indkam te $\propto$ Kong, so hun: Do cest mogtig tyk! - Ja, so hand, vi lowwer å hear godt ả Lyksborre. Så spuu hand hind, va hun vild decer. Hun vild nåk ha hind Sön Peor jem, hand va Soldåt; hun kund it laww, væn hand it jemm va, a hind Ko dand vild a it frece, vœn Peœr it ve en jemm va. - Ja, so hand, Peœr kund hun it få jem, de var a bcecest Soldåt te hand ho. Så gik hand hon $i$ ce Skatol å ga hind ti Spets Dåler; no sku hun kuns gå jem, vaen Pcæer ho sin Ti uurtiend, så kam hand å jem. 
(Der var en gammel Kone fra Langbjerg, hendes Mand var død. Hun havde een S $\varnothing n$, han hed Per; han var Soldat, han tjente ved Livgarden i København. Hun vilde nok til Lyksborg for at tale med Kongen. Så gik hun af Sted med Træsko med Messingkramper om, og Paraplyen under Armen. Da hun ankom til Lyksborg, spurgte hun Skildvagten, om hun ikke måtte tale med Kongen. Så kom Tjeneren og sagde, hun skulde komme ind. Da hun så kom ind til Kongen, sx́gde hun: Du est mægtig tyk! - Ja, sagde han, vi lever også godt her på Lyksborg. Så spurgte han hende, hvad hun vilde der. Hun vilde nok have $\sin$ S $\not$ n Per hjem, han var Soldat; hun kunde ikke leve, når han ikke var hjemme, og hendes Ko den vilde heller ikke æde, når Per ikke var hjemme has den. - Ja, sagde han, Per kunde hun ikke få hjem, det var den bedste Soldat han havde. Så gik han hen i Chatollet og gav hende ti Speciedaler; nu skulde hun blot gå hjem, når Per havde tjent sin Tid ud, så kom han også hjem).

Blandt de Ting, der særpræger denne Text, kan, foruden de mange eæ, oa, ie fremdrages to: De mange tyske Låneord: Leibgarde, Skirm, frece, og en Rest af den gammeldanske Personbøjning i Verberne: Do es $t$ magtig tyk. Begge disse Ejendommeligheder genfinder vi i endnu mere udpræget Grad i Sydslesvigsk.

F jol d e m å le t. Rim og Ordsprog optegnede 1931-32 af Forf. efter Tinne Carstensen i Bjerrup, Carsten Hansen på Kollund Mark og Carsten Carstensen i Fjolde.

Skodåger der kun i ar Eeng, da kun vi goa ruoler i Seeng; skodåger der åw i ar Hie, da æer ar Ræejn rie.

Der lyssener a der donneker, der sier så groat $i$ ar $S k ø j$; Åch Gott, di stakkels Hiereker, di eer så långt froa ar Bøj.

Far a Muor a Sønner di voor sammel om an Sild: Far tåw der imceld Håwwer a Skcert, di ander kund taj som di vild. 
Vet du ha mce, da kat du foa mce;

var w hær, der hor ce oa ma,

var we tien der fortær $\propto$,

såndt $\propto r \propto$.

Di groa Moarner a da uund Kunner di vuur beer når viider åp oa ar Daw.

Taej din Fœtter i Agt, œejs trin ce dœe, såw ar Kåk te ar Hcest.

(Sødugger det kun i Engen - Verbet sødugge bruges om Aftentåge i Eng og Mose - så kan vi gå rolige i Seng; sødugger det også i Heden, så er Regnen rede. - Det lyner og det tordner, det ser så gråt ud i Skyen; å Gud, de stakkels Hyrdedrenge de er så langt fra Byen. - Far og Mor og Sønner de var sammen om en Sild: Far tog det mellem Hoved og Stjært (Hale), de andre kunde tage som de vilde. - Vil du have mig, så kan du få mig, hvad jeg har, det har jeg på mig, hvad jeg tjener, det fortærer jeg, sådan er jeg. - De grå Morgener og de onde Koner de bliver bedre noget længere op på Dagen. - Tag Vare på dine Fødder, ellers træder jeg på dig, sagde Hanen til Hesten).

Altså sånt $\propto r$ ce, men di e e $r$ så långt froa ar $B ø j$, du $k a t$ foa ma, men vi $k u n$ goa ruoler $i$ Seeng. I Fjoldemålet er ikke blot Verbernes Personbøjning, men også deres Talbøjning bevaret $\mathrm{i}$ stor Udstrækning. Det hedder $a$ ar, du aest, hand cer, vi eer, im eer (Pronominet I har i Fjolde den mærkelige Form im), di eer; det hedder $\propto$ vår, du våst, hand vår, vi, im, di voor. $E$ voer (jeg bliver), du varst, han vœr, men vi, im, di vuur; ce hcer, vi ha; œ kand, du kat, vi kun; œ kømmer, vi kom; we fecr, vi foa; hand skyder, di skyt; ce gik, du gikst, vi ging.

Mange vil måske finde, at denne omstændelige Bøjning minder om slidsomme Tysktimer. Mien der er slet ikke tale om nogen tysk Påvirkning. Lyngby har påvist, at Fjoldemålet med Hensyn til Verbernes Bøjning stemmer overens med ældre Dansk og på afgørende Punkter afviger fra Tysk, fx ved at mangle Personbøjning i visse nøje afgrænsede Tilfælde: 1 . i 
pluralis, 2. i præteritum singularis af de svage Verber og i præsens singularis af alle Verber undtagen Hjælpeverber som have, være, kunne; i Tysk har alle Verber jo Personbøjning, både de stærke og de svage, både i præteritum og i præsens, både i singularis og pluralis. Et endnu bedre Bevis på, at Verbernes Fersonbøjning i Fjoldemålet ikke skyldes tysk Indflydelse, er Former som $d u$ kat og $d u$ vet med -t, ikke -st som i tysk $d u$ kannst, du willst; disse Former stemmer overens med gammeldanske Former som thu kant og thu wilt.

Verbernes Person- og Talbøjning er nu praktisk talt forsvundet på hele det danske Dialektområde, også i Nord-og Mellemslesvig. Vi har jo set, at det på Rømø hedder di vår, di kommer, vi har, $u$ for vi joen, i Hvidding Herred de $k a$ do stool å, på Sundeved e’ do da mondt tumbe, kand do, vil do, di skyrre, og i Frøslev do ha, hvor kan do tro så tombe og fær vi. Bedst holdt 2. Person præsens singularis af Verbet vcere sig: do cest anvendes på Lyngbys Tid i Mellemslesvig og også et Stykke op i Nordslesvig som en særlig emfatisk Form ved Siden af do ær; det er en sådan Anvendelse vi har iagttaget $\mathbf{i}$ den lille Prøve på Angelbomålet. Pluralisbøjningen holdt sig bedst i Bydemåden: I hele Sønderjylland husker de ældre endnu, at man sagde kom ind å scet dce neer, når man talte med een, men kommer ind å scetter jer neer, når man talte til flere. Man sagde Farvel til een og Farrevel til flere. I Afstemningsdigtet fra Als råber Forfatteren „Komme, komme, komme!" ved Synet af Dannebrogsflagene, fordi han kalder på alle Husets Folk (på Als ligesom på Sundeved er $\mathrm{r}$ stumt i Udlyd).

Det er altså først i Løbet af de seneste Hundrede År, at de sidste Rester af Verbernes Person- og Talbøjning er forsvundet i Nord- og Mellemslesvig. Og de er forsvundet under Påvirkning nordfra. Årsagen til, at Fjoldemålet har bevaret denne Bøjning, er den, at Påvirkningerne fra Nord altid har haft vanskelig ved at trænge så langt mod Syd. 
Derfor er også mange andre Ejendommeligheder bevaret, som er gået tabt i de andre jyske Dialekter, fx en hel Del Gl os e r. En Karl og en Pige hedder i Fjolde an Svan og an Myø; at love hedder a jat; heraf kommer Betegnelsen for det gamle Forlovelsesgilde, Jatteryøl; at synge hedder a kveo; at hient Barn, et hedent Barn, betyder et udøbt Barn; i Fjolde sagde Værtinden Tæej Mar oa ar Bryø (tag Mad på Brødet); her har Ordet Mad nemlig bevaret den ældgamle Betydning „Kød“.

Fjoldemålet isolerede sig altså for Påvirkninger nordfra: men det må en Tid lang have modtaget Påvirkninger fra Øst, fra de danske Øer, formodentlig gennem Sydangel. Disse Påvirkninger kan belyses ved et Exempel.

I Middelalderens jyske Sprogkilder hedder præteritum af Verbet brannce (brænde) brandce med d. I de fleste jyske Dialekter hedder det brceœnd, brænnd (med palataliseret n) og lignende, og disse Former kan udledes af brændæ. På Øerne hedder det derimod de fleste Steder brcente eller lignende, med $t$ i Stedet for $d$ ligesom $i$ Rigssproget. I Fjolde siger man breendt med langt $e$, palataliseret $n$ og $t$. Denne Form kan ikke udledes af brændæ, da vi skulde vente breend med langt e, palataliseret $n$ og ikke noget $t$, ligesom cendce (Ende) modsvares af Fjoldemålets eend. Den kan heller ikke udledes af et ældre dansk brænte, fordi æ foran nt ellers modsvares af kort $i$ i Fjolde: hint (hente), vint (vente). Den kan kun forstås, nảr vi antager, at Fjoldemålet først har haft den ventede jyske Form breend (langt $\mathrm{e}+$ palataliseret $\mathrm{n}$ ) og at $\mathrm{t} i$ forholdsvis sen Tid er føjet til under Påvirkning fra Ømålene.

Men Forbindelsen mod Øst blev afbrudt, da den danske Dialekt i Sydangel var forstummet. Nu stod Fjoldemålet helt isoleret, og nye Kulturimpulser kunde nu kun komme sydfra, gennem Nedertysk og Højtysk. I Fjolde Sogn tog Sprogskiftet forholdsvis lang Tid, så Nedertysk fik Tid til at påvirke den danske Dialekt stærkt.

På hvilke Punkter blev nu Fjoldemålet påvirket af Nedertysk, inden det forsvandt? Svaret må i Korthed blive dette: 
Selve Sprogets Udtrykssystem synes kun i ringe Grad påvirket; dets Vokaler og Konsonanter er stort set uændrede og afviger stærkt fra det nedertyske Vokal- og Konsonantsystem. Kun een ny Konsonant, nemlig ch, er trængt ind med de tyske Låneord. Derimod er visse Udtaleejendommeligheder nedertyske, først og fremmest den udtryksfulde Sætningsbetoning. Hvad Sprogets I n d h old (Betydningssiden) angår, er de mest centrale og abstrakte Dele uændret; fx er den danske Forskel mellem Aktiv og Passiv bevaret, skønt denne Forskel ikke findes i Nedertysk. Derimod har Nedertysk i meget høj Grad påvirket den mindre abstrakte Del af Dialektens Betydningsside, først og fremmest ved at tilføre den et overvældende Antal tyske Låneord og Vendinger, der er oversat fra Tysk.

Det er disse tyske Lån, der gør, at Brydningen mellem gammelt og nyt fremtræder langt tydeligere i Fjoldemålet end i nogen anden dansk Dialekt. Nogle Exempler.

Det danske Ord fiin betyder „findelt"; når Fjoldeboen skal udtrykke den anden Betydning, dette Ord har på Dansk, nemlig „fornem", må han bruge det højtyske Låneord fajn. An Grawstien er en gammeldags lav Gravsten, am no ha di jo bald old Dankmåler (men nu har de jo næsten alle moderne Gravmonumenter).

Julemanden hedder ar Viinachsman. Gamle Tinne fortalte, at $\mathbf{i}$ hendes Barndom plejede Børnene Juleaften at sætte en Tallerken hen i ar Slavinding (det Vindue i Dagligstuen, som kunde åbnes), så sku Kinneken kom - det oer jo ar Viinachsman - a fyør var deceri. Der vår jo an Frøwwer. Som a vår at let Myø, da fœek a at Par Handklunger $i$ ar Fatjen (så skulde Kindeken komme - det var jo Julemanden - og føre noget $i$ den. Det var jo en Glæde (Frøwwer er et nedertysk Låneordd). Da jeg var en lille Pige, da fik jeg et Par Vanter i ar Fatjen). Det sidste Ord er sammensat af det danske Ord Fad og den nedertyske Diminutivendelse -jen. Denne Endelse (og Sideformen -ken) er meget almindelig i Fjoldemålet. At Skutjen (Skjorte + jen) er en Barneskjorte, at Grytjen en lille 
Gryde, at Puosjen (Pose + jen) et Barnesvøb; œn Hier er en Hyrde, at Hiereken en Hyrdedreng; at Teeskieken er en Teske.

Kinneken er identisk med det højtyske Kindchen, der $\mathbf{i}$ Forbindelse med ovennævnte Skik bruges om Jesusbarnet. Kinneken-Skikken er eller har været almindelig i de fleste Egne i Tyskland, og til Fjolde er den kommet sydfra.

Mange af de Folkeskikke og Trosforestillinger, som Folklorister er letsindige nok til at anse for danske og urgamle, når de finder dem i Angel i tysk Sprogdragt, afslører sig på den eleganteste Måde som sene tyske Indvandrere, når vi træffer dem i dansk Sprogdragt i Fjolde. Svarende til Folkesagnenes Nisser og Underjordiske, som driller Gårdens Folk på forskellig Vis, finder vi her Ynderertsker (nedertysk Unnerirdschen). Varsel hedder Fåryøwen (nedertysk Vöröben); der kand råk yøw får, sej som (det kan nok varsle, siger nogle), fortæller Tinne forsigtigt, am o har just ingen Truo decrte (men jeg har just ingen Tiltro til det).

Nedertyske Låneord er vistnok trængt ind pả alle mulige Betydningsområder. Der findes dog områder, hvor de gør sig stærkere gældende end på andre. Fjoldeboerne har vist lettere ved at bruge stærke Udtryk end Nordslesvigerne, som ellers ikke tor betegnes som Sinker i denne Henseende. Fx ejer Fjoldemålet flere Midler til at udtrykke det i m p o n e rende $i$ en Foreteelse end de fleste andre Dialekter. Jeg besøgte en Gang Tinne i Regnvejr og roterede bl. a. de Kommentarer, hun benyttede til det dårlige Vejr i Løbet af en halv Times Tid: Der or at grysseler Veer, at skrckkeler Veer; der or rient at Nyøveer (Nødvejr); der ös nier ma Gevalt; der oer rent an Grywl mce sånt Veer; at bøøs brusker Veer. Oftest er det Låreord, der bruges: Der vår doch at bandich Svin, eller an greesich guo Stuur; hand hor an lomsk Masser Pcending (Penge) eller ufårnünftich myl (meget) Pcending.

Når man tænker på, hvor nøjsomt Livet i gamle Dage har 
formet sig dernede på den magre Sandjord, undres man ikke over, at Fjoldeboerne har gode danske Ord for Sparso mm e l i g h e d. Man skal være skoansom ved sit Tøj, og en Husmoder bør være sparsom og synner (det sidste Ord er lånt fra Nedertysk). Mere påfaldende er det, at Ordforrådet er så rigt, når det gælder nedsættende Betegnelser for overdreven Sparsommelighed; her er det eneste danske Ord purreker ...påholdende"; samme Betydning har det tyske kniper; an Knipsak er en påholdende Mand; det stærkeste Ord er det tyske gitser "gerrig".

Også Ord for Dygtighed, Raskhed og Flid er for en meget stor Del nedertyske Lån. An flitteler Mand er en arbejdsom Mand; men når man kan kalde ham halat (Tryk på sidste Stavelse) eller flink, er han flittig og rask til sit Arbejde; samme Betydning har de to Ord i Nedertysk. Der $\infty$ tuorlai var an ar døchter ajter ek (der er Forskel på - es ist zweierlei - om man er dygtig eller ikke). Danske er de karakteristiske Udtryk for, at et Redskab falder en Karl let og naturligt i Hảnden: Hand hoer at gåt Greb deceroa, eller at gåt Slaw dexroa; men tyske Låneord har vi i: Hun oer så genau a så akkuråt, hun hcelder oa Rienlekai (hun holder på Reinlichkeit). For de forskellige Arter og Grader af Udygtighed findes et særdeles righoldigt Forråd af Ord og Udtryk, nogle af dansk, flere af tysk Oprindelse. I Betydningen „doven“ findes to Adjektiver, et ældre og et yngre Låneord, nemlig låj og fuul. For mangelfuld Begavelse findes det danske Adjektiv bageler og desuden det tyske Udtryk svach i ar Håwwer; i den sidste Betydning bruges også Vendingen han hæer var væch $i$ ar Håwwer (han har noget borte -- dvs. mangler noget - i Hovedet).

Denne sydslesvigske Dialekt viser os i forstørret Målestok de to Hovedejendommeligheder ved alle de sønderjyske Dialekter, mest udpræget $\mathrm{i}$ de sydlige, mindst $\mathrm{i}$ de nordvestlige. Den ene er de tyske Låneord; for Nordslesvig kan næv- 
nes Kost, som i nogle Egne har erstattet det danske Ord Bryllup, sat, der bruges for mæt, og Boll, der har fortrængt Tyr. Den anden er den, at gamle Træk, som er forsvundet andetsteds, er bevaret; Exempler er nævnt ovenfor, her skal til Slut nævnes et Par gamle Ord: Blee (et Lagen). Bøøst (en Skinke), øof (at råbe).

Vi glæder os ofte over disse gamle Ejendommeligheder. Men Studiet af Fjoldemålet og dets Skæbne viser os klart, at de har en Årsag, som kan blive farlig, nemlig Isolation.

Efter Genforeningen er alle Sluser åbnet, som før holdt Påvirkninger nordfra ude, og Nordslesvigs Dialekter har i de sidste 33 År gennemgået en Omdannelsesproces så voldsom som måske ingen Sinde før. Mange gamle Ejendommeligheder, som vi satte Pris på, er forsvundet; og ofte er de erstattet af mindre lødigt Sprogstof. Fine Nuancer er gået tabt, klare og djærve Sætninger, hvis Forløb det var en Fryd for Tanken at følge, er nu forældet. Men i Stedet er det danske Rigssprog i al sin Rigdom og Skønhed nu tilgængeligt for alle danske Sønderjyder; og det er dette Rigssprog der alene kan bevare dansk Tankegang og dansk Sindelag i Sønderjylland. 